\title{
Pertumbuhan dan Kandungan Vitamin C Tanaman Kangkung Darat (Ipomoea reptans Poir) pada Media Zeolit dengan Penambahan Asam Humat
}

\author{
Adhelia Syefanis*, Elly Proklamasiningsih, Iman Budisantoso
}

Fakultas Biologi, Universitas Jenderal Soedirman

Jalan dr. Suparno 63 Purwokerto 53122

*Email: adhelias02@gmail.com

Rekam Jejak Artikel:

Diterima : 22/08/2019 Disetujui : 18/10/2019

\begin{abstract}
Ipomoea reptans Poir is the most favoured vegetable that mostly known by the people because in addition having good nutrition content, it is one type of vitamin $\mathrm{C}$ good source other than fruits. Vitamin $\mathrm{C}$ is an antioxidant which is required by the body to maintain the immune of body from the damaging effect of free radicals. The addition of organic compound in the form of humic acid that has a complex structure with high molecular weight and contains an active group that can increase the growth and productivity of plants. The high availability of nutrients require a carrier such as zeolite. Zeolite is a silicate mineral which have a high cation exchange capacity (CEC) (varying between $80-180 \mathrm{meq} / 100 \mathrm{~g}$ ). The addition of zeolite as a carrier is expected to increase the production of food crops such as corn. This study aimed to know the effect of humic acid with zeolite growth media for the growth and vitamin C content in Ipomoea reptans Poir and also and to determine the concentration of humic acid that most effect to the growth and vitamin $\mathrm{C}$ content in Ipomoea reptans Poir. The research was conducted at the Laboratory of Plant Physiology and Greenhouse, Faculty of Biology, Jenderal Soedirman University, Purwokerto by using experimental methods. The research was conducted from January 2019 to March 2019 with using completely randomized design (CRD). The parameters were observed in this study are the number of leaves, plant fresh weight, dry weight of plants, and vitamin $\mathrm{C}$ content. The data were analyzed by analysis of variance at the level of $95 \%$ and $99 \%$, then following by analytical analysis BNT 95\%. The results of this research showed that the addition of humic acid with a concentration of $4 \mathrm{~g}^{\mathrm{kg}} \mathrm{kg}^{-1}$ zeolite growing media can increaseIpomoea reptans Poir growth and the addition of humic acid to the zeolite growth media cannot increase the vitamin $\mathrm{C}$ content of Ipomoea reptans Poir.

Keywords:Ipomoea reptansPoir, vitamin $C$, zeolite, humic acid
\end{abstract}

\begin{abstract}
Abstrak
Kangkung darat (Ipomoea reptans Poir) merupakan sayuran yang paling digemari oleh masyarakat selain memiliki kandungan gizi yang baik dan salah satu sumber vitamin $\mathrm{C}$ selain buah-buahan. Vitamin C merupakan antioksidan yang dibutuhkan oleh tubuh manusia untuk menjaga daya tahan tubuh dari efek buruk radikal bebas. Pemberian bahan organik berupa asam humat yangmemiliki struktur molekul kompleks dengan berat molekul tinggi dan mengandung gugus aktif dapat meningkatkan pertumbuhan dan produktivitas tanaman. Untuk meningkatkan keterediaan unsur hara diperlukan bahan pembawa (carrier) berupa zeolit.Zeolit merupakan mineral silikat yang memiliki kapasitas tukar kation (KTK) yang sangat tinggi (bervariasi antara 80-180 meq/100g). Pemberian bahan humat dengan carrier zeolit diharapkan dapat meningkatkan produksi tanaman pangan seperti tanaman jagung. Penelitian ini bertujuan untuk mengetahui pengaruh asam humat dengan media tanam zeolit terhadap pertumbuhan dan kandungan vitamin $\mathrm{C}$ pada tanaman kangkung darat dan untuk menentukan konsentrasi asam humat yang paling berpengaruh terhadap pertumbuhan dan kandungan vitamin $\mathrm{C}$ pada tanaman kangkung darat. Penelitian dilaksanakan di Laboratorium Fisiologi Tumbuhan dan Greenhouse, Fakultas Biologi Universitas Jenderal Soedirman, Purwokerto dengan menggunakan metode eksperimental. Penelitian ini dilaksanakan dari Januari 2019 hingga Maret 2019 dengan menggunakan rancangan percobaan yaitu Rancangan Acak Lengkap (RAL). Parameter yang diamati pada penelitian ini adalah jumlah daun, berat basah tanaman, berat kering tanaman, dan kandungan vitamin C. Data dianalisis dengan analisis ragam pada taraf kepercayaan $95 \%$ dan 99\%, dan dilanjutkan dengan analisis BNT pada taraf kepercayaan 95\%. Hasil penelitian menunjukkan bahwa pemberian asam humat dengan konsentrasi 4 g. $\mathrm{kg}^{-1}$ pada media tanam zeolit dapat meningkatkan pertumbuhan tanaman kangkung darat,dan pemberian asam humat pada media tanam zeolit tidak dapat meningkatkan kandungan vitamin $\mathrm{C}$ kangkung darat.

Kata kunci: Kangkung darat, vitamin C, zeolit, dan, asam humat
\end{abstract}




\section{PENDAHULUAN}

Kangkung darat mengandung vitamin A, B, C, protein, kalsium, fosfor, sitosterol dan mineral terutama zat besi yang berguna bagi pertumbuhan dan kesehatan tubuh manusia(Irawati \& Salamah, 2013). Vitamin C kangkung darat dapat mencegah dan menyembuhkan sariawan dan gusi berdarah (Savitri, 2016), sebagai antioksidan dan untuk membentuk kolagen, serat, dan struktur protein (Kurniawan et al., 2010). Selain pada manusia Vitamin C pada tumbuhan berperan sebagai agen antioksidan yang dapat menetralkan singlet oksigen yang sangat reaktif serta berperan dalam pertumbuhan sel (Davey et al., 2006).

Vitamin C dapat disintesis dari D-glukosa dan D-galaktosa dalam tumbuhan maupun hewan. Sumber vitamin $\mathrm{C}$ terdapat pada buah-buahan dan sayuran (Naidu, 2003)Karbohidrat merupakan senyawa prekursor yang berperan dalam pembentukan vitamin C. Jenis karbohidrat dalam pembentukan vitamin $\mathrm{C}$ yaitu glukosa yang selanjutnya masuk jalur biosintesis vitamin $\mathrm{C}$ melalui jalur asam D-glukoronat dan L-gulonat (Noviati et al., 2012).

Asam humat dengan carrier zeolit dapat meningkatkan kadar nitrogen pada daun tanaman jagung sehingga pertumbuhan tanaman meningkat melalui peningkatan bobot akar dan tinggi tanaman. Zeolit merupakan mineral silikat yang memiliki kapasitas tukar kation (KTK) yang sangat tinggi bervariasi antara 80-180 meq/100g media tanam karena ukuran struktur rongga zeolit yang sesuai dengan ukuran ion amonium (Suwardi, 2009). Penyerapan unsur hara yang baik akan meningkatkan pertumbuhan tanaman dan metabolisme tumbuhan salah satunya peningkatan laju fotosintesis (Ayuso et al., 1996).

Tujuan penelitian ini mengetahui pengaruh asam humat pada media tanam zeolit terhadap pertumbuhan dan kandungan vitamin $\mathrm{C}$ tanaman kangkung darat, serta menentukan konsentrasi asam humat yang paling berpengaruh terhadap pertumbuhan dan kandungan vitamin $\mathrm{C}$ kangkung darat.

\section{MATERI DAN METODE}

Bahan yang digunakan antara lain kangkung darat, zeolit, asam humat, vitamin $\mathrm{C}$, asam oksalat, $\mathrm{H}_{2} \mathrm{SO}_{4} 5 \%$, ammonium molibdat $5 \%$, etanol $96 \%$. Penelitian termasuk eksperimental dengan Rancangan Acak Lengkap (RAL). Perlakuan terdiri dari 5 konsentrasi asam humat 0 g. $\mathrm{kg}^{-1}, 4$ g. $\mathrm{kg}^{-1}, 8$ g. $\mathrm{kg}^{-1}, 12$ g. $\mathrm{kg}^{-1}$, dan 16 g. $\mathrm{kg}^{-1}$ media tanam. Setiap perlakuan diulang tiga kali sehingga diperoleh 15 unit percobaan.Pengamatan dilakukan setelah 2 minggu terdiri dari berat basah, berat kering tanaman, jumlah daun dan kandungan vitamin C.Setiap polybag berisi 3-4 bibit berumur 1 minggu yang dipelihara selama 4 minggu. Pengamatan jumlah daun dilakukan 1 dan 2 minggu setelah penanaman. Daun yang telah dikeringkan diekstrak dengan etanol.

Pembuatan larutan standar dari larutan stok vitamin C 1000 ppm masing-masing 0,2 ml, 0,3 ml, $0,4 \mathrm{ml}, 0,5 \mathrm{ml}, 0,6 \mathrm{ml}, 0,7 \mathrm{ml}$ dan $0,8 \mathrm{ml}$, ditambahkan $4 \mathrm{ml} \mathrm{H} 2 \mathrm{SO} 45 \%$ dan amonium molibdat 5\% hingga $10 \mathrm{ml}$. Inkubasi 30 menit suhu ruang, kemudian diukur serapan pada panjang gelombang $570 \mathrm{~nm} .10 \mathrm{mg}$ ekstrak etanol daun kangkung darat dilarutkan dengan etanol 96\%. $1 \mathrm{ml}$ ekstrak ditambahkan $\mathrm{H} 2 \mathrm{SO} 4 \quad 5 \% \quad 4 \quad \mathrm{ml}$ serta amonium molibdat $5 \%$ hingga $10 \mathrm{ml}$, homogenkan dan inkubasi 30 menit suhu ruang. Diukur pada panjang gelombang $570 \mathrm{~nm}$. Kadar vitamin C dihitung dengan rumus $y=a x+b$. Dimana $x$ konsentrasi (mg. $\left.\mathrm{g}^{-1}\right)$, dan y hasil absorbansi. Nilai a dan $b$ adalah nilai konstanta dan arah regresi yang diperoleh dari kurva standar.

Analisis data menggunakan ANOVA (Analysis of Varians) $95 \%$ dan $99 \%$ dilanjutkan analisis Uji Beda Nyata Terkecil (BNT) 5\%.

\section{HASIL DAN PEMBAHASAN}

\section{Pengaruh media zeolit dengan penambahan asam humat pada pertumbuhan}

Uji viabilitas benih kangkung darat memiliki daya kecambah sebesar $95 \%$ yang berarti benih mempunyai daya kecambah yang baik sehingga dapat digunakan untuk penelitian. Penambahan asam humat pada media tanam zeolit berpengaruh nyata terhadap jumlah daun, berat basah dan berat kerin, serta tidak berpengaruh nyata terhadap kandungan vitamin $\mathrm{C}$ (Tabel 1).

Tabel 1. Pengaruh media zeolit dengan penambahan asam humat pada pertumbuhan kangkong darat

\begin{tabular}{cccc}
\hline Perlakuan & Jumlah Daun & Berat Basah (gram) & $\begin{array}{c}\text { Berat Kering } \\
(\text { gram })\end{array}$ \\
\hline AH0 (kontrol) & $6,667 \mathrm{~b}$ & $4,8207 \mathrm{bc}$ & $0,4397 \mathrm{c}$ \\
AH1 $\left(4 \mathrm{~g} \cdot \mathrm{kg}^{-1}\right)$ & $14,000 \mathrm{a}$ & $9,2683 \mathrm{a}$ & $0,7520 \mathrm{a}$ \\
AH2 $\left(8 \mathrm{~g} \cdot \mathrm{kg}^{-1}\right)$ & $5,333 \mathrm{~b}$ & $3,5600 \mathrm{~d}$ & $0,3047 \mathrm{~d}$ \\
AH3 $\left(12 \mathrm{~g} \cdot \mathrm{kg}^{-1}\right)$ & $6,000 \mathrm{~b}$ & $3,6163 \mathrm{~cd}$ & $0,3703 \mathrm{~cd}$ \\
AH4 $\left(16 \mathrm{~g} \cdot \mathrm{kg}^{-1}\right)$ & $5,667 \mathrm{~b}$ & $5,3813 \mathrm{~b}$ & $0,5367 \mathrm{~b}$ \\
\hline
\end{tabular}


Kosentrasi 4 g.kg- ${ }^{1}$ merupakan konsentrasi asam humat yang paling baik untuk meningkatkan pertumbuhan tanaman kangkung darat. Meningkatnya pertumbuhan kangkung darat meliputi jumlah daun, berat basah dan berat kering, berkaitan dengan peranan asam humat yang dapat meningkatkan ketersediaan unsur hara pada media tanam zeolit. Asam humat mampu meningkatkan ketersediaan dan pengambilan unsur hara melalui kemampuan tanaman mengikat, menjerap dan mempertukarkan unsur hara dan air. Unsur hara esensial yang dibutuhkan tanaman terdiri dari unsur hara makro dan unsur hara mikro dapat meningkat karena adanya penambahan asam humat pada media tanam zeolit.

Asam humat yang terdapat pada media tanam zeolit memiliki unsur gugus fungsional seperti $\mathrm{COOH},-\mathrm{OH}$ fenolat maupun $-\mathrm{OH}$ alkoholat sehingga asam humat dapat membentuk senyawa kompleks dengan ion logam yang sebelumnya berikatan dengan unsur hara yang terdapat pada media tanam zeolit (Alimin, 2000). Zeolit memiliki KTK yang tinggi yang mana KTK tinggi dapat menyebabkan peningkatan kemampuan pertukaran kation (Senda et al., 2009).

Zeolit terdiri dari kristal alumino silikat terhidrasi yang mengandung kation alkali atau alkali tanah dalam kerangka tiga dimensi. Ion-ion alkali tersebut dapat diganti oleh kation lain tanpa merusak struktur zeolit dan dapat menyerap air secara reversibel. Selain itu zeolit memiliki ukuran struktur rongga yang sesuai dengan ukuran ion ammonium sehingga memiliki daya serap yang tinggi terhadap ion ammonium (Suwardi, 1991).

Sembiring et al. (2016) menyatakan bahwa dengan penambahan asam humat dapat meningkatkan penyerapan unsur hara terutama unsur $\mathrm{N}$ dan P. Semakin banyak unsur $\mathrm{N}$ dan $\mathrm{P}$ yang diserap tanaman maka proses pembelahan dan pembesaran sel daun akan menjadi lebih baik. Hal ini sesuai dengan pendapat Hardjowigeno (2003) yang menyatakan bahwa unsur $\mathrm{N}$ dan $\mathrm{P}$ membantu pembelahan dan pembesaran sel sehingga daun muda cepat mencapai bentuk yang sempurna dan mendorong pertumbuhan tanaman. Penambahan asam humat dapat memenuhi ketersediaan unsur hara sehingga meningkatkan berbagai proses fisiologis tergantung nutrisi dan pengembangan morfologi (Baldotto, 2013).

Pertumbuhan gladiol lebih tinggi karena aplikasi asam humat juga bisa disebabkan oleh stimulasi metabolisme $\mathrm{N}$ dan aktivitas fotosintesis, peningkatan luas daun dan hasil akhirnya lebih tinggi. Semakin banyak jumlah daun yang dihasilkan maka semakin meningkat pula berat basah dan berat kering pada tanaman (Sembiring et al., 2016). Hal ini sesuai nilai korelasi yang menyatakan jumlah daun memiliki hubungan korelasi positif terhadap berat basah dengan nilai korelasi sebesar $\mathrm{R}=0,920$ dan berat basah memiliki hubungan korelasi terhadap berat kering dengan nilai korelasi $\mathrm{R}=0,964$ begitupun dengan berat kering memiliki hubungan korelasi yang positif terhadap jumlah daun dengan nilai korelasi sebesar $\mathrm{R}=0,856$. Meningkatnya penyerapan unsur hara mempengaruhi laju fotosintesis dan juga kandungan protein sehingga perkembangan tanaman menjadi meningkat dan akan menghasilkan berat kering tanaman yang tinggi (Gardner et al., 2007).

\section{Kandungan Vitamin C Kangkung Darat pada Media Zeolit dengan Penambahan Asam Humat}

Hasil analisis ragam menunjukkanpemberian asam humat pada media tanam zeolit tidak berpengaruh nyata terhadap kandungan vitamin $\mathrm{C}$ tanaman kangkung darat. Pemberian asam humat 4 g. $\mathrm{kg}^{-1}$ berpengaruh nyata terhadap pertumbuhan sehingga menghasikan pertumbuhan yang optimal selain itu juga akan menghasilkan hasil fotosintesis yang optimal tetapisenyawa hasil dari metabolisme primer berupa glukosa tidak dapat menghasilkan vitamin C secara maksimal. Glukosa mempunyai peran penting sebagai sumber energi, sumber karbon dan untuk mengatur sinyal yang mempegaruhi ekspresi gen dalam proses pembentukan metabolit sekunder (Ramawat,1999).

Dicosmo (1989) menyatakan sumber karbon dapat menginduksi pembentukkan metabolit sekunder dan pada konsentrasi tinggi karbohidrat dapat mempertahankan metabolisme sekunder. Dalam sel tumbuhan, karbohidrat mempengaruhi pembentukan metabolit sekunder melalui glikolisis dan daur Krebs. Glukosa yang terbentuk kemudian akan masuk kedalam proses biosintesis vitamin $\mathrm{C}$ melalui jalur asam D-glukoronat dan L-gulonat untuk membentuk asam askorbat (Manitto, 1981).

Valpuesta \& Botella (2004) menyatakan dalam tahapan proses biosintesis vitamin $\mathrm{C}$ melalui jalur asam D-glukoronat dan L-gulonat dimulai dari tahap pengubahan glukosa-6-fosfat menjadi glukosa-1-fosfat sampai akhirnya membentuk asam askorbat tidak selalu berjalan dengan searah atau sejalan melainkan pada biosintesis vitamin $\mathrm{C}$ dijalur asam D-glukoronat dan L-gulonat terdapat tahapan lainnya salah satunya yaitu terjadi proses oksidasi yang merupakan proses kerusakan dan penurunan vitamin C. Oksidasi merupakan reaksi pelepasan elektron oleh sebuah molekul, atom, atau ion dalam reaksi kimia (Andarwuan \& koswara, 1992). Secara umum reaksi oksidasi vitamin C ada dua macam yaitu proses oksidasi spontan dan proses oksidasi tidak spontan. Proses oksidasi spontan adalah proses oksidasi yang terjadi tanpa menggunakan enzim atau katalisator. Sedangkan proses oksidasi tidak spontan yaitu reaksi yang terjadi dengan adanya perubahan enzim atau katalisator, misal enzim glutation. Enzim ini 
adalah suatu tripeptida yang terdiri dari asam glutamate, sistein, dan glisin. Sehingga vitamin C yang dihasilkan melalu jalur asam D-glukoronat dan L-gulonat tidak maksimal.

Vitamin C di alam dapat terbentuk sebagai asam L-askorbat dan asam L-dehidroaskorbat, keduanya mempunyai keaktifan sebagai vitamin C. Asam askorbat sangat mudah teroksidasi secara reversible menjadi asam L-dehidroaskorbat. Asam L-dehidroaskorbat secara kimia sangat labil dan mengalami perubahan lebih lanjut menjadi asam L-diketogulonat yang tidak memiliki keaktifan vitamin C lagi (Cresna et al., 2014)

\section{SIMPULAN}

Penambahan asam humat pada media tanam zeolit mampu meningkatkan pertumbuhan tetapi tidak dapat meningkatkan kandungan vitamin $\mathrm{C}$ pada tanaman kangkung darat dan Konsentrasi asam humat yang palig berpengaruh untuk meningkatkan pertumbuhan pada tanaman kangkung darat yaitu pada konsentrasi 4 g. $\mathrm{kg}^{-1}$

\section{DAFTAR REFERENSI}

Alimin, 2000. Fraksinasi Asam Humat dan Pengaruhnya pada Kelarutan Ion Logam Seng (II), Kadmium (II), Magnesium (II) dan Kalsium (II). Thesis kimia. Yogyakarta: Universitas Gadjah Mada Pogram pascasarjana.

Andarwulan, N. \& Koswara, S., 1992. Kimia Vitamin. Jakarta: Rajawali Press.

Ayuso, M., Hernandez, T., Garcia, C. \& Pascual, A.J., 1996. A Comparative Study Of The Effect On Barley Growth Of Humic Subtances Extracted From Municipal Wastes And From Traditional Organic Material. J sci food agric, 72, pp.493-500.

Baldotto, M.A. \& Baldotto , E.B., 2013. Gladiolus Development In Response To Blub Treatment With Different Concentrations Of Humic Acids. 60(1), pp.138-42.

Cresna, Mery, N., \& Ratman., 2014. Analisis Vitamin C Pada Buah Pepaya, Sirsak, Srikaya Dan Langsat Yang Tumbuh Di Kabupaten Donggala. J. Akademika Kim. 3(3), pp. 346-353.

Davey, M.W., Kenis, K. \& Keulemans, J., 2006. Genetic Control of Fruit Vitamin C Contents. Plant Physiology , 142, pp.34351.

Dicosmo, F. 1989. Tissue Culture Secondary Metabolism. Toronto: Bio International Inc.

Gardner, P., Frankin , B.R., Pearce \& Roger, L.M., 2007. Fisiologi Terjemahan Oleh Herawati, Susilo. Jakarta: UI.
Hardjowigeno, S., 2003. Ilmu Tanah Ultisol. Jakarta: Akademika Pressindo.

Ihdaryanti, M.A., 2011. Pengaruh Asam Humat Dan Cara Pemberiannya Terhadap Pertumbuhan Dan Produktivitas Tanaman Padi (Oryza sativa). Bogor: Institut Pertanian Bogor.

Irawati \& Salamah , Z., 2013. Pertumbuhan Tanaman Kangkung Darat (Ipomoea reptans Poir) Dengan Pemberian Pupuk Organik Berbahan Dasar Kotoran Kelinci. Jurnal Bioedukatika, 1(1), pp.1-96.

Kurniawan, M., Munifatul, I. \& Yulita, N., 2010. Kandungan Klorofil, Karotenoid, dan Vitamin C pada Beberapa Spesies Tumbuhan Akuatik. Buletin Anatomi dan Fisiologi, 18(1), pp.28-40.

Manitto, P. (1981). Biosintesis Produk Alami.Terjemahan : Koensoemardiyah. Semarang: Press Semarang.

Naidu, K.A., 2003. Vitamin C In Human Health And Disease Is Still A Mystery An Overview. Nutrition Journal, 2(7), pp.1-10.

Noviati, A., Yulita, N. \& Nintya, S., 2012. Respon Pertumbuhan dan Produksi Senyawa Antioksidan pada Kalus Hibiscus sabdarifa L. dari Eksplan yang Berbeda Secara in vitrio 22(1), pp. 25-29..

Ramawat, K.G. 1999. Production in culture: optimation. In Ramawat,K.G. and J.M. Merillon. (eds). Biotechnology Secondary Metabolites.New Hampchire: Science Publisher, Inc.

Savitri, A., 2016. Tanaman Ajaib. Basmi Penyakit dengan TOGA (Tanaman Obat Keluarga). Depok: Bibit Publisher.

Sembiring, J.V., Nelvia, N. \& Yulia, A.E., 2016. Pertumbuhan Bibit Kelapa Sawit (Elais guineensis Jaca) Di Pembibitsn Utama Pada Medium Sub Soil Ultisol Yang Diberi Asam Humat Dan Kompos Tandan. Jurnal Agroteknologi , 6(1), pp.25-32.

Senda, S.P., Saputra, H., Sholeh, A. \& Rosjidi, M., 2009. Prospek Aplikasi Produk Berbasis Zeolit Untuk Slow Release Subtances (SRS) Dan Membran.Artikel Badan Pengkaji Dan Penerapan Teknologi Indonesia,ISSN 1410-9891.

Suwardi, 1991. Pemanfaatan Zeolit Sebagai Media Tumbuh Tanaman. Tokyo: PPI-Jepang.

Suwardi, 2009. Teknik aplikasi zeolit dibidang pertanian sebagai bahan pembenah tanah. Jurnal Zeolit Indonesia, 8, pp.33-38.

Valpuesta, V. \& Botella, M.A., 2004. Biosynthesis Of L-Ascorbix Acid In Plants: New Pathway For An Old Antioxidant. Trends In Plants Science, 9(12), pp.573-576. 